\title{
Egg rejection behavior does not explain the lack of cowbird parasitism on an eastern North American population of Red-winged Blackbirds
}

\author{
Justin J. Reel and Todd J. Underwood ${ }^{*}$ (1)
}

\begin{abstract}
Background: Red-winged Blackbirds (Agelaius phoeniceus), hereafter red-wings, are much less frequently parasitized by Brown-headed Cowbirds (Molothrus ater) in eastern North America than in central North America and had not been recorded as hosts in our study area in southeastern Pennsylvania. Although hosts of Old World cuckoos (Cuculidae) often show geographic variation in egg rejection behavior, cowbird hosts typically exhibit uniform responses of all acceptance or all rejection of cowbird eggs. Thus, geographic variation in cowbird parasitism frequencies might reflect a different behavioral response to parasitism by hosts where only some populations reject parasitism. In this study, we tested whether egg rejection behavior may explain the lack of parasitism observed in our eastern red-wing population, which may provide insight into low parasitism levels across eastern North America.
\end{abstract}

Methods: We parasitized red-wing nests with model cowbird eggs to determine their response to parasitism. Nests were tested across three nest stages and compared to control nests with no manipulations. Because rejection differed significantly by stage, we compared responses separately for each nest stage. We also monitored other songbird nests to identify parasitism frequencies on all potential hosts.

Results: Red-wings showed significantly more rejections during the building stage, but not for the laying and incubation stages. Rejections during nest building involved mostly egg burials, which likely represent a continuation of the nest building process rather than true rejection of the cowbird egg. Excluding these responses, red-wings rejected $15 \%$ of cowbird eggs, which is similar to rejection levels from other studies and populations. The overall parasitism frequency on 11 species surveyed in our study area was only 7.4\%.

Conclusions: Egg rejection behavior does not explain the lack of parasitism on red-wings in our eastern population. Alternatively, we suggest that cowbird preference for other hosts and the low abundance of cowbirds in the east might explain the lack of parasitism. Future research should also explore cowbird and host density and the makeup of the host community to explain the low levels of parasitism on red-wings across eastern North America because egg rejection alone is unlikely to explain this broad geographic trend.

Keywords: Brood parasitism, Brown-headed Cowbird, Egg rejection, Geographic variation, Red-winged Blackbird 


\section{Background}

The fitness costs of obligate brood parasitism put a strong selection pressure on host species to evolve defenses against parasitism (Rothstein 1990). Frontline defenses, such as cryptic nest placement and aggressive nest defense, may prevent nests from being parasitized (Feeney 2017), whereas egg rejection behavior is the most effective defense to mitigate the costs of parasitism after it has occurred (Rothstein 1975; Ruiz-Raya and Soler 2017). Egg rejection may involve grasp or puncture ejection of the parasite's egg by the host (Soler et al. 2002; Underwood and Sealy 2006a), burial of a parasite's egg under a new nest (Sealy 1995; Moskát and Honza 2002), or nest desertion (Moksnes et al. 1991; Hosoi and Rothstein 2000). Hosts of Old World cuckoos (Cuculidae) often show behavioral plasticity in their egg rejection behavior (Ruiz-Raya and Soler 2017). For example, the egg rejection response of cuckoo hosts can vary with the risk of parasitism over time (Soler et al. 1998; Thorogood and Davies 2013) and over large geographic areas (Liang et al. 2016). By contrast, most Brown-headed Cowbird (Molothrus ater), hereafter cowbird, hosts are either all accepters or all rejecters of cowbird eggs (Peer and Sealy 2004). Rarely, however, hosts show geographic variation in their response to cowbird parasitism. For example, eastern Warbling Vireos (Vireo gilvus gilvus) with slightly larger bills generally eject cowbird eggs, whereas western Warbling Vireos (Vireo gilvus swainsoni) generally accept cowbird eggs (Sealy 1996; Sealy et al. 2000; Underwood and Sealy 2006a). Frequencies of observed cowbird parasitism on Warbling Vireos in different geographic areas reflect this different rejection response (Gardali and Ballard 2000; Ortega and Ortega 2003).

Cowbird parasitism on Red-winged Blackbirds (Agelaius phoeniceus), hereafter red-wings, shows considerable variation by year, location, and habitat (Yasukawa and Searcy 2019). However, observed parasitism frequencies also appear to vary on a large geographic scale across North America (Friedmann et al. 1977) that suggests there also may be geographic variation in the response of red-wings to cowbird eggs. Assumed historical patterns of sympatry with cowbirds on the Great Plains (Mayfield 1965) would predict a higher egg rejection frequency by red-wings in central North America, but recent studies suggest that cowbirds were more widespread in North America prior to European settlement (Rothstein and Peer 2005; Peer et al. 2013). Furthermore, a review of the published literature showed cowbird parasitism highest in central populations and uniformly very low to absent in eastern populations (Table 1, Appendix). In southern Quebec for example, Terrill (1961) noted the near lack of cowbird parasitism on red-wings here was similar to the
Table 1 Average Brown-headed Cowbird parasitism frequency on Red-winged Blackbird nests for three regions across North America based on a review of the literature

\begin{tabular}{lcccc}
\hline Region & Nests examined & $\begin{array}{l}\text { Nests } \\
\text { parasitized }\end{array}$ & \% Parasitized & Range (\%) \\
\hline West & 6658 & 368 & 5.5 & $0.0-12.5$ \\
Central & 11,077 & 1888 & 17.0 & $0.0-100$ \\
East & 10,798 & 186 & 1.7 & $0.0-8.3$ \\
\hline
\end{tabular}

Data are compiled from studies in Appendix. See Appendix for definitions of the three regions

rarity of parasitism on two known rejecters of cowbird eggs. Although red-wings have been found to generally respond to experimental cowbird eggs by accepting them (Rothstein 1975; Ortega and Cruz 1988; Ward et al. 1996; Capper et al. 2012), these tests were mostly conducted in central and western North America. There has been little detailed behavioral study of their responses to cowbird parasitism in eastern North American populations and responses have not been examined across all nest stages. Even though red-wings are considered accepters, they have occasionally been observed to eject cowbird eggs, bury cowbird eggs, or desert parasitized nests (Rothstein 1975; Weatherhead 1989; Yasukawa and Werner 2007; Capper et al. 2012). Thus, the first step in understanding the low levels of parasitism in eastern North America is to determine if any of these populations are rejecters of cowbird eggs.

In this study, we experimentally parasitized red-wing nests in our study area of Berks County, Pennsylvania to determine if they reject cowbird eggs as a first step in understanding the lack of parasitism on red-wings here (Appendix). Red-wing nests were experimentally parasitized at different stages (nest building through incubation) because some host species are known to respond differently to cowbird parasitism by nest stage (e.g., Sealy 1995) and to get a complete assessment of their response to parasitism. The nest building stage has rarely been tested in other cowbird hosts in part because this may not represent a true response to parasitism (Rothstein 1975). However, eggs added prior to laying are often rejected by hosts that otherwise accept most cowbird eggs (e.g., Peer and Bollinger 1997), so parasitism at this stage may help identify whether eastern red-wings possess the physical traits and behaviors needed to reject cowbird eggs. We hypothesized that the lack of parasitism on red-wings in this eastern population reflects a higher level of cowbird egg rejection than other researchers have documented in central and western red-wing populations. In addition, we report cowbird parasitism frequencies on other potential hosts 
in our Berks County, PA study area through active nest searching and a review of the literature to document the cowbird host community here, which may provide evidence to identify possible alternate hypotheses for the lack of cowbird parasitism.

\section{Methods}

Our field sites were the Peter's Creek area at Lake Ontelaunee, Berks County, Pennsylvania $\left(40^{\circ} 27^{\prime} 39.9^{\prime \prime} \mathrm{N}\right.$, $75^{\circ} 53^{\prime} 55.4^{\prime \prime} \mathrm{W}$ ), and natural areas on Kutztown University campus, in Kutztown, Berks County, Pennsylvania $\left(40^{\circ} 30^{\prime} 40.6^{\prime \prime} \mathrm{N}, 75^{\circ} 47^{\prime} 32.5^{\prime \prime} \mathrm{W}\right)$. We searched wetland and riparian habitats to find red-wing and other songbird nests from May to July 2018. Data were collected in two phases, an experimental phase and a surveying phase.

During the experimental phase, we parasitized redwing nests with model cowbird eggs (Fig. 1) during three stages of nest development (nest building, egg laying, and incubation) and used a control group where no manipulations occurred. We used the control group to account for any rejection responses, especially nest desertion, that may be the result of general disturbance from human visitation of nests (e.g., Rothstein 1975; Yasukawa and Werner 2007) or recognition errors in the absence of parasitism (e.g., Sealy 1995; Moskát and Hauber 2007). Nests were randomly assigned to one of these four treatments within sets of four nests. To maintain approximately equal sample sizes across treatments, we added treatments back into the available pool when nests failed. Each nest was used only once for an experimental treatment.

We added a single model cowbird egg to each nest at the assigned treatment stage and monitored the nest for five consecutive days. Building treatments received a model egg at the first evidence of nest lining being added.
Laying treatments received a model egg on the day the first or second red-wing egg was laid. Incubation treatments received a model egg after the nest had reached full clutch size, or more specifically, after 2 days of no additional egg laying. Control treatments did not receive a model egg but were monitored for five consecutive days after the first egg was laid or the nest was found. We classified egg rejection responses as egg burial when eggs were covered over by nest material, egg ejection when a model egg (or host egg in a control nest) was missing and there was no sign of predation, or as nest desertion when the model egg and host eggs were present (or just host eggs in a control nest) but the eggs were cold and the nest was not tended by parents for at least two consecutive days. Nests that were lost due to weather or predation events were recorded as such and left out of the final analysis. After 5 days, if the nest was still active, we assumed the model egg was accepted and removed it.

Model cowbird eggs were created using prefabricated wooden model eggs. Model eggs were very close in size to real cowbird eggs. Real eggs measure $21.5 \mathrm{~mm} \times 16.4 \mathrm{~mm}$ $($ range $=18.03 \mathrm{~mm} \times 15.49 \mathrm{~mm}-25.40 \mathrm{~mm} \times 16.76 \mathrm{~mm})$ (Lowther 1993), and model eggs averaged $22.4 \pm 0.23 \mathrm{~mm}$ $\times 16.2 \pm 0.22 \mathrm{~mm}(n=42)$. We drilled out the cores of these wooden models and filled them with steel spheres ( $\sim 4.5 \mathrm{~mm}$ diameter and $\sim 0.3 \mathrm{~g}$ mass) to add mass until they were as close as possible to the average cowbird egg mass. Real eggs weighed $3.1 \mathrm{~g}$ (Lowther 1993), and the average mass of model cowbird eggs was $3.0 \pm 0.1 \mathrm{~g}$. We sealed the hole with wood filler and painted the eggs to match the appearance of cowbird eggs with non-toxic acrylic paint. Eggs were given a base coat of FolkArt 901 Wicker White paint, then speckled using FolkArt 940 Coffee Bean brown paint and a toothbrush. Finally, we applied a coat of Minitaire D6-198-2 Satin Coat

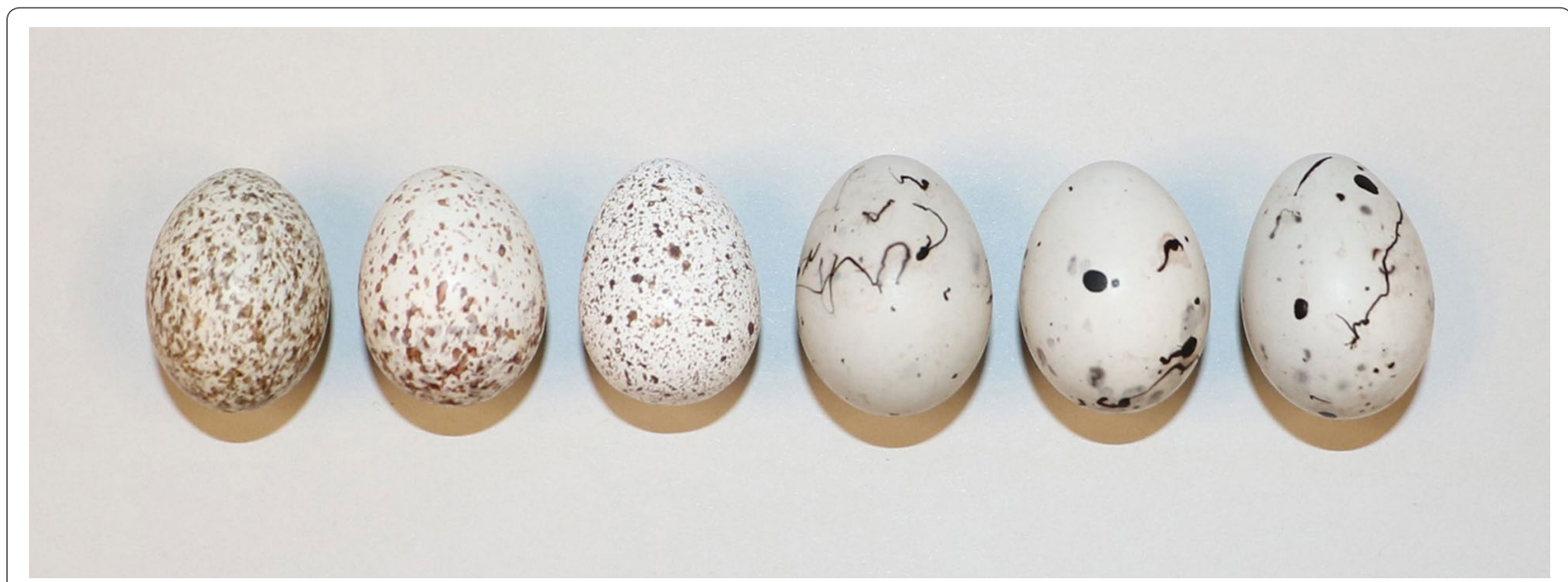

Fig. 1 Model Brown-headed Cowbird egg used in this experiment compared to real eggs. Illustrated from left to right are: two real cowbird eggs, one model cowbird egg, and three Red-winged Blackbird eggs 
water-based clear coat to each egg to ensure paint integrity under wet conditions. These same paints have been used to create model cowbird eggs that elicit rejection responses similar to real cowbird eggs in other species (e.g., Underwood and Sealy 2006b) and other species respond similarly to wooden model cowbird eggs and real cowbird eggs (e.g., Peer and Bollinger 1997).

During the surveying phase, we located nests of any songbirds on our study areas. Nests were monitored until they reached a full clutch to determine cowbird parasitism frequencies among local hosts. We also visually compared these parasitism frequencies to those on common hosts in Berks County, Pennsylvania in the late 19th century from egg collection data (Uhrich 1997). These two sets of data document the cowbird host community in our study areas, which may provide evidence to suggest potential alternate hypotheses for the lack of cowbird parasitism.

To analyze experimental data, we first determined whether red-wing's response to parasitism differed by nest stage using a $4 \times 2$ Fisher's exact test because observed or expected values were less than 5 . Because behavioral responses to experimental parasitism were significantly different by nest stage (Fisher's Exact Test two-tailed, $p=0.001, n=56$ ), we could not pool data across nest stages. Instead, we compared responses for each stage to the control separately to determine whether red-wings rejected experimental parasitism and adjusted the alpha level using the Bonferroni correction for making multiple comparisons (Critical $p$-value $=0.017$ ). We used Fischer's exact tests for these multiple comparisons because observed or expected values were less than 5 .

\section{Results}

Red-wings showed significantly more rejection behavior during the nest building stage than at control nests (Fisher's Exact Test two-tailed, $p<0.001, n=15$ Building, 14 Control). Most of the rejections during the building stage were burials ( $44 \%$ of rejections), but all three methods of rejection were recorded during this stage (Table 2). Although these rejections may not be a direct response to parasitism, this demonstrates that all rejection behaviors are present in our population, including ejection. Egg ejection likely indicates the physical ability to graspeject these solid cowbird eggs, but we did not confirm this directly. By comparison, rejection responses did not differ significantly between the laying stage and control nests (Fisher's Exact Test two-tailed, $p=0.309, n=14$ Laying, 14 Control) and the incubation stage and control nests (Fisher's Exact Test two-tailed, $p=0.057, n=13$ Incubation, 14 Control). Red-wings accepted $85.2 \%$ of experimental cowbird eggs across the laying and incubation nest stages. None of the accepted cowbird eggs had any evidence of peck marks indicating that red-wings attempted puncture ejection.

Parasitism frequencies were relatively low on all species during the 2018 breeding season (Table 3). The frequency of natural parasitism on red-wing nests was $1.6 \%$ of 64 total nests (includes experimentally parasitized nests and failed nests not used in experiments) and $0.0 \%$ of 14 control nests (with no manipulations). Cowbird eggs were found in the nests of five of 11 species of songbirds and parasitism frequencies on these species was generally $\leq 50 \%$ (Table 3). Egg collection data from the late 19th century in Berks County, Pennsylvania showed similar levels of parasitism on these same species (Table 3).

\section{Discussion}

Red-wings accepted $85 \%$ of all model cowbird eggs during the laying and incubation stages, which classifies this eastern population as "accepters" with $<21 \%$ rejection (Peer and Sealy 2004). These results were consistent with prior studies that found rejection frequencies to be in the "accepter" range in central (Capper et al. 2012) and western North America (Ortega and Cruz 1988; Ward et al. 1996) and in multiple regions of North America combined (Rothstein 1975). By comparison, a much higher rejection frequency $(60 \%)$ was found during nest building. These rejections mostly involved the burial of cowbird eggs but also included a few ejections and desertions (Table 2). Rothstein (1975) suggested that burial of cowbird eggs is a continuation of the nest building process rather than an anti-parasite response because host eggs are not buried as well. We found that red-wings only buried model

Table 2 Response of Red-winged Blackbirds in Berks County, Pennsylvania to experimental model cowbird eggs added to their nests at different stages of the nest cycle and at control nests

\begin{tabular}{|c|c|c|c|c|c|c|c|}
\hline Treatment & Rejected & Ejected & Buried & Deserted & Accepted & Total $(n)$ & Rejected (\%) \\
\hline Building & 9 & 3 & 4 & 2 & 6 & 15 & 60.0 \\
\hline Laying & 1 & 1 & 0 & 0 & 13 & 14 & 7.1 \\
\hline Incubation & 3 & 2 & 0 & 1 & 10 & 13 & 23.1 \\
\hline Total for laying and incubation & 4 & 3 & 0 & 1 & 23 & 27 & 14.8 \\
\hline Total across treatments & 13 & 5 & 4 & 3 & 29 & 42 & 31.0 \\
\hline Control & 0 & 0 & 0 & 0 & 14 & 14 & 0.0 \\
\hline
\end{tabular}


Table 3 Cowbird parasitism frequencies on common host species in Berks County, Pennsylvania

\begin{tabular}{|c|c|c|c|c|c|}
\hline \multirow[t]{2}{*}{ Host species } & \multirow[t]{2}{*}{ Scientific name } & \multicolumn{2}{|c|}{2018 breeding season } & \multicolumn{2}{|c|}{ Late 19th century ${ }^{a}$} \\
\hline & & $n$ & $\%$ parasitized & $n$ & $\%$ parasitized \\
\hline Willow Flycatcher ${ }^{b}$ & Empidonax traillii & 2 & 0.0 & - & - \\
\hline Eastern Phoebe & Sayornis phoebe & 1 & 100 & $u_{n k}{ }^{c}$ & unk \\
\hline Red-eyed Vireo ${ }^{d}$ & Vireo olivaceus & - & - & 10 & 30.0 \\
\hline Wood Thrush & Hylocichla mustelina & 13 & 0.0 & 31 & 0.0 \\
\hline American Robin & Turdus migratorius & 10 & 0.0 & 13 & 0.0 \\
\hline Gray Catbird & Dumetella carolinensis & 19 & 0.0 & 45 & 0.0 \\
\hline Brown Thrasher & Toxostoma rufum & 1 & 0.0 & 36 & 0.0 \\
\hline Chipping Sparrow & Spizella passerina & 4 & 25.0 & 24 & 41.7 \\
\hline Field Sparrow & Spizella pusilla & 3 & 33.3 & 33 & 21.2 \\
\hline Song Sparrow & Melospiza melodia & 8 & 12.5 & 33 & 21.2 \\
\hline Eastern Towhee & Pipilo erythrophthalmus & - & - & 26 & 0.0 \\
\hline Yellow Warbler & Setophaga petechia & 2 & 50.0 & 1 & 0.0 \\
\hline Northern Cardinal & Cardinalis cardinalis & 6 & 0.0 & 4 & 0.0 \\
\hline Indigo Bunting & Passerina cyanea & - & - & 29 & 24.1 \\
\hline Totals & & 68 & 7.4 & 285 & 11.9 \\
\hline
\end{tabular}

a Data from Levi Mengel egg collection (1884-1900) in the Reading Public Museum (Uhrich 1997)

b No nests of the Willow Flycatcher or the very similar Alder Flycatcher were previously reported in Berks County, although birds of both species were observed during the breeding season (Uhrich 1997)

c Total number of nests and parasitism frequency unknown but 8 nests recorded as parasitized and this species was noted as a common host

d Species lacking data from the 2018 breeding season (indicated by dashes) were present in our study areas but at a low density and no nests were located

cowbird eggs and not host eggs during the nest building stage. Rejection of eggs or objects prior to egg laying also may be a nest sanitation response (Guigueno and Sealy 2012, but see Peer 2017). Interestingly, $40 \%$ of cowbird eggs were accepted during nest building, which suggests some red-wings did not view these eggs as debris and were able to add lining material to the nest without burying them. In addition, desertion of parasitized red-wing nests is higher prior to egg laying and may simply be a general response to disturbance at the nest (Yasukawa and Werner 2007). Thus, rejections of model cowbird eggs during the nest building stage are not clearly responses to the cowbird egg. Nevertheless, these responses suggest that red-wings in our population possess the behaviors and physical attributes needed for all three methods of egg rejection behavior. Rejection was not expressed during the laying or incubation stages likely due to an evolutionary lag in the appearance of cowbird egg recognition (Rothstein 1975) because even red-wing populations in central North America where there is a reasonably high probability of parasitism are accepters (e.g., Capper et al. 2012). Overall, the hypothesis that lack of cowbird parasitism on our eastern red-wing population may reflect a higher level of cowbird egg rejection than has been previously documented in other red-wing populations was not supported. However, there are several possible alternative explanations for the lack of cowbird parasitism on our eastern population of red-wings.
Asynchrony between breeding seasons of cowbirds and their hosts can alter host use by cowbirds. Low frequencies of parasitism on some accepter species, such as American Goldfinches (Spinus tristis) and Eastern Wood-Pewees (Contopus virens), has been linked to the late nesting period of these hosts after most cowbirds have laid their eggs (Middleton 1977; Underwood et al. 2004). However, in Pennsylvania, red-wing eggs have been recorded from 1 May through 25 June, whereas cowbirds egg dates have been recorded from 1 May through 18 June (McWilliams and Brauning 2000). Thus, the cowbird breeding season completely overlaps the red-wing breeding season here and breeding season asynchrony does not explain the lack of parasitism in our eastern population.

Nest defense is the first line of defense birds can utilize to prevent brood parasitism (Welbergen and Davies 2009). Red-wings in particular are well known for responding aggressively to nest threats, particularly the presence of cowbirds (e.g., Capper et al. 2012; Yasukawa et al. 2016). In some host species, nest defense intensity has been observed to differ geographically between host populations based on their sympatry with brood parasites (Briskie et al. 1992; Røskaft et al. 2002; Gill and Sealy 2004, but see Kuehn et al. 2016). However, red-wings have been found to show either similar levels of aggression toward cowbirds in areas of presumed recent and historic sympatry with cowbirds (Prather et al. 1999) or 
higher levels of aggression toward cowbirds in areas of presumed historic sympatry compared to recent sympatry with cowbirds (Yasukawa et al. 2016). Finally, aggressive nest defense by red-wings against cowbirds does not always reduce their parasitism frequency (Strausberger 2001; Yasukawa et al. 2016), so there is no evidence to suggest that higher levels of nest defense might explain the lack of parasitism in any eastern red-wing population.

Despite the abundant source of host nests provided by the red-wings' breeding colonies, cowbird parasitism was previously not detected in red-wing nests in Berks County and we found a very low level of cowbird parasitism on red-wings in our study areas in 2018 (Appendix), which suggests they may not be preferred hosts here. The most heavily parasitized species in our study area were sparrows (Table 3). Perhaps these species were preferred here because they are smaller than cowbirds (Friedmann et al. 1977; Freeman et al. 1990; Strausberger and Ashley 1997) and were found in edge habitats (Johnson and Temple 1990). Alternatively, the density of the cumulative host community can have a strong influence on cowbird parasitism levels on individual species (Barber and Martin 1997). In our specific study areas, the density of hosts other than red-wings and known ejecters of cowbird eggs, American Robins and Gray Catbirds (Rothstein 1975), appeared to be relatively low, so perhaps other higher quality habitats with denser host communities in the broader region were preferred by cowbirds. However, a large number of factors have been found to be related to cowbird parasitism frequencies in different study areas (Curson et al. 2010) and community levels of parasitism are difficult to predict (Hahn and Hatfield 1995). Future research should consider multiple variables related to differences in host community composition and host density to explain broader geographic trends in cowbird parasitism of red-wing nests.

Finally, cowbird abundance may be an important factor explaining the lack of parasitism in our red-wing population and possibly the uniformly low parasitism frequencies observed in eastern North America. We rarely encountered more than one female cowbird per day on our study areas (Reel and Underwood personal observations) and documented a relatively low frequency of parasitism across all potential songbird hosts (Table 3). Because cowbird parasitism frequencies are positively related to cowbird density (Igl and Johnson 2007), geographic trends in cowbird abundance may help explain the broader trend in cowbird parasitism frequencies as well. Cowbirds are most abundant today in the Great Plains (Peterjohn et al. 2000), and their abundance is negatively related to the distance from the Great Plains (Thompson et al. 2000). Furthermore, cowbirds are declining in abundance in the east while increasing in abundance in the Northern Great Plains (Peterjohn et al. 2000). Community parasitism studies in central North America, where cowbirds are more abundant, have found higher parasitism frequencies for many other hosts relative to eastern parasitism frequencies. For example, Field Sparrows experience 11 to $80 \%$ parasitism on central nests compared to 0.2 to $21.2 \%$ parasitism on nests in Pennsylvania (Uhrich 1997; Carey et al. 2008). Overall, the lower abundance of cowbirds in eastern North America should be further explored as an explanation for the low frequencies of parasitism observed on red-wings and other hosts here.

\section{Conclusion}

In conclusion, a higher level of cowbird egg rejection behavior in Red-winged Blackbirds was not supported as a cause of the low parasitism frequencies in our eastern North American population. We found that red-wings accepted most model cowbird eggs during the laying and incubation stages, which is similar to prior studies in central and western North America. Acceptance of cowbird parasitism in our population is likely due to an evolutionary lag in the appearance of egg recognition because we found that red-wings have the physical attributes and behaviors needed for egg rejection. Breeding season asynchrony is also not likely responsible for the observed parasitism frequencies because the breeding seasons of cowbirds and red-wings overlap completely in our area. Previous research on nest defense behavior does not suggest that red-wings in the east are more aggressive towards cowbirds. We suggest that the lower observed parasitism frequencies in our eastern population may be due to the relatively low abundance of cowbirds here and cowbirds' preferences for other hosts as they relate to host size and density. Future research should explore multiple factors, such as cowbird and host density and the makeup of the host community, in addition to egg rejection to explain the low levels of observed parasitism on Red-winged Blackbirds across eastern North America because egg rejection behavior alone is unlikely to explain this broad geographic trend.

\section{Acknowledgements \\ We thank Kutztown University and the Neag family for funding our research and the Reading Area Water Authority for permission to conduct our study at Lake Ontelaunee. We also thank Brian Peer, Spencer Sealy, and four anony- mous reviewers for comments that improved our manuscript, Taylor Nash for field assistance, and Rudy Keller for advice on field sites. Finally, TJU thanks Hawk Mountain Sanctuary for research space and use of their library while revising our manuscript.}

\section{Authors' contributions}

TJU conceived the study. JJR and TJU designed the study and conducted field work. JJR performed the statistical analysis and wrote the first draft of the manuscript. JJR and TJU discussed and revised the manuscript. Both authors read and approved the final manuscript. 


\section{Funding}

Funding was provided by a BEARS Grant and a Neag Undergraduate Research Grant from Kutztown University. The funding agency played no role in the design of the study, data collection and analysis, interpretation, and writing of the manuscript.

\section{Availability of data and materials}

All data generated or analyzed during this study are included in this published article.

Ethics approval and consent to participate

Research was approved by the Kutztown University Institutional Animal Care and Use Committee (protocol \#2018-02). Fieldwork was conducted under permits from the Pennsylvania Game Commission (scientific study permit
\#42924) and the US Fish and Wildlife Service (scientific collecting permit \#MB78073C-0).

Consent to publish

Not applicable.

Competing interests

The authors declare that they have no competing interests.

\section{Appendix}

See Table 4.

Table 4 A review of Brown-headed Cowbird parasitism frequencies on Red-winged Blackbird nests across North America

\begin{tabular}{llll}
\hline State/province County/area & Nests examined & $\begin{array}{l}\text { Nests } \\
\text { parasitized frequency }\end{array}$ & $\begin{array}{l}\text { Parasitism References } \\
\text { frequencina }\end{array}$
\end{tabular}

(\%)

\begin{tabular}{|c|c|c|c|c|c|}
\hline \multicolumn{6}{|l|}{ West $^{a}$} \\
\hline $\mathrm{BC}$ & Westham Island & $\sim 1400$ & 3 & 0.2 & Picman (1986) \\
\hline $\mathrm{BC}$ & Provincewide & 1416 & 28 & 2.0 & Campbell et al. (2001) \\
\hline $\mathrm{BC}$ & Okanagan Valley & 107 & 1 & 1.0 & Ward and Smith (2000) \\
\hline$B C$ & Okanagan Valley & 258 & 29 & 11.2 & Cannings et al. (1987) \\
\hline CA & Fresno County & 4 & 0 & 0.0 & Verner and Ritter (1983) \\
\hline CA & Central Valley & 85 & 6 & 7.1 & Payne (1973) \\
\hline WA & Grant County & 1325 & 102 & 7.7 & Freeman et al. (1990) \\
\hline WA & Columbia National Wildlife Refuge & 2039 & 198 & 9.7 & Orians et al. (1989) \\
\hline WA & Whitman County & 24 & 3 & 12.5 & King (1954) \\
\hline West total & & 6658 & 368 & 5.5 & \\
\hline \multicolumn{6}{|l|}{ Central } \\
\hline $\mathrm{CO}$ & Boulder County & 591 & 14 & 2.4 & Vierling (2000) \\
\hline $\mathrm{CO}$ & Boulder County & 295 & 47 & 15.9 & Carello and Snyder (2000) \\
\hline $\mathrm{CO}$ & Boulder County & 79 & 21 & 26.6 & Ortega et al. (1994) \\
\hline $\mathrm{CO}$ & Boulder County & $97^{b}$ & 5 & 5.2 & Ortega et al. (1994) \\
\hline $\mathrm{CO}$ & & 802 & 78 & 9.7 & Ortega (1991) in Ortega (1998) \\
\hline $\mathrm{CO}$ & & 37 & 1 & 2.7 & $\begin{array}{l}\text { Ortega and Ortega unpub. data in Ortega } \\
\text { (1998) }\end{array}$ \\
\hline $\mathrm{CO}, \mathrm{WY}$ & & 154 & 27 & 17.5 & Hanka (1979) \\
\hline IA & Northern IA & 343 & 40 & 11.7 & Delphey and Dinsmore (1993) \\
\hline IA & Dickinson County & 98 & 32 & 32.7 & Lowther (1983) \\
\hline IL & & 200 & 25 & 12.5 & Merrill et al. (2017) \\
\hline IL & Scott County & $150^{b}$ & 44 & 29.3 & Peer (2017) \\
\hline IL & Dupage County & 139 & 52 & 37.4 & Strausberger (2001) \\
\hline IL & Coles County & 344 & 5 & 1.5 & Peer and Bollinger (1997) \\
\hline IL & statewide & 217 & 6 & 2.8 & Robinson et al. (2000) \\
\hline $\mathrm{IL}, \mathrm{AR}$ & & 653 & 14 & 2.1 & Smith (1949) \\
\hline KS & Flint Hills & 670 & 147 & 21.9 & Rivers et al. (2010) \\
\hline KS & Douglas County & 73 & 22 & 30.1 & Fleischer (1986) \\
\hline KS & Riley County & 29 & 9 & 31.0 & Facemire (1980) \\
\hline KS & Riley County & 1 & 1 & 100.0 & Elliott (1978) \\
\hline $\mathrm{KS}, \mathrm{NE}, \mathrm{MO}$ & & 51 & 3 & 5.9 & Lowther (1977) \\
\hline KS & Ellis County & 228 & 50 & 21.9 & Hill (1976) \\
\hline LA & & 754 & 12 & 1.6 & Goertz (1977) \\
\hline MB & Delta Marsh & $153^{b}$ & 3 & 2.0 & Capper et al. (2012) \\
\hline MB & Delta Marsh & 37 & 9 & 24.3 & Underwood and Sealy (2008) \\
\hline
\end{tabular}


Table 4 (continued)

\begin{tabular}{|c|c|c|c|c|c|}
\hline State/province & County/area & Nests examined & $\begin{array}{l}\text { Nests } \\
\text { parasitized }\end{array}$ & $\begin{array}{l}\text { Parasitism } \\
\text { frequency } \\
\text { (\%) }\end{array}$ & References \\
\hline MB & Delta Marsh & 394 & 60 & 15.2 & Woolfenden et al. (2004) \\
\hline MB & Delta Marsh & 213 & 42 & 19.7 & Neudorf and Sealy (1994) \\
\hline MB & Delta Marsh & 382 & 132 & 34.6 & Weatherhead (1989) \\
\hline ND & Richland and Ransom Counties & 55 & 14 & 25.5 & Pietz et al. (2009) \\
\hline ND & Statewide & 786 & 339 & 43.1 & Igl and Johnson (2007) \\
\hline ND & South central ND & 93 & 40 & 43.0 & Koford et al. (2000) \\
\hline ND & Cass County & 258 & 109 & 42.2 & Linz and Bolin (1982) \\
\hline ND & Arrowwood National Wildlife Refuge & 17 & 13 & 76.5 & Houston (1973) \\
\hline NE & Eastern and south-central NE & 59 & 32 & 54.2 & Hergenrader (1962) \\
\hline OK & Marshall County & 73 & 2 & 2.7 & Ely (1957) in Wiens (1963) \\
\hline OK & Marshall County & 33 & 0 & 0.0 & Wiens (1963) \\
\hline OK & Osage and Washington Counties & 205 & 40 & 19.5 & Patten et al. (2006) \\
\hline SD & Lincoln County & 53 & 28 & 52.8 & Blankespoor et al. (1982) \\
\hline WI & Rock County & 1942 & 291 & 15.0 & Yasukawa et al. (2016) \\
\hline WI & Diehls Prairie & 319 & 79 & 24.8 & Clotfelter and Yasukawa (1999) \\
\hline Central total & & 11,077 & 1888 & 17.0 & \\
\hline \multicolumn{6}{|l|}{ East } \\
\hline MD & Statewide & 1000 & 2 & 0.2 & Robbins and Blom (1996) \\
\hline Ml & & $>1000$ & 3 & 0.3 & Walkinshaw (1991) \\
\hline Ml & Cheboygan and Emmet Counties & 44 & 0 & 0.0 & Southern and Southern (1980) \\
\hline Ml & & 1300 & 7 & 0.5 & Nickell (1955) \\
\hline Ml & Washtenaw County & 99 & 5 & 5.1 & Berger (1951) \\
\hline NY & Ithaca & $>100$ & 0 & 0.0 & Henger and Hauber (2014) \\
\hline NY & New York City & 12 & 1 & 8.3 & Henger and Hauber (2014) \\
\hline NY & Dutchess County & 35 & 0 & 0.0 & Hahn and Hatfield (1995) \\
\hline ON & Provincewide & 6027 & 163 & 2.4 & Peck and James (1987) \\
\hline PA & Berks County & 45 & 0 & 0.0 & $\begin{array}{l}\text { Unpublished data from Reading Public } \\
\text { Museum }\end{array}$ \\
\hline PA & Berks County & $64^{\mathrm{b}}$ & 1 & 1.6 & This study \\
\hline QC & Southern QC & $1000^{c}$ & 2 & 0.2 & Terrill (1961) \\
\hline SC & Charleston County & 72 & 2 & 2.8 & Whitehead et al. (2002) \\
\hline East total & & 10,686 & 185 & 1.7 & \\
\hline
\end{tabular}

a We divided North America into three general geographic areas. West included all states and provinces west of the Rocky Mountains. Central included states and provinces from the Rocky Mountains east through Manitoba, Minnesota, and Wisconsin south to Louisiana. East included all states and provinces from the east coast west through Ontario, Michigan, and Indiana south to Mississippi

b Includes experimentally parasitized nests

c Reported as "less than $0.2 \%$ parasitism" with two nests parasitized of "many hundreds" examined. We estimated 1000 nests inspected to calculate this frequency

Received: 1 August 2019 Accepted: 3 December 2019

Published online: 26 December 2019

\section{References}

Barber DR, Martin TE. Influence of alternate host densities on Brownheaded Cowbird parasitism rates in Black-capped Vireos. Condor. 1997;99:595-604

Berger AJ. The cowbird and certain host species in Michigan. Wilson Bull. 1951:63:26-34.

Blankespoor GW, Oolman J, Uthe C. Eggshell strength and cowbird parasitism of Red-winged Blackbirds. Auk. 1982;99:363-5.
Briskie JV, Sealy SG, Hobson KA. Behavioral defenses against avian brood parasitism in sympatric and allopatric host populations. Evolution 1992:46:334-40

Campbell RW, Dawe NK, McTaggart-Cowan I, Cooper JM, Kaiser GW, Stewart AC, et al. The birds of British Columbia, Vol. 4. Vancouver: UBC Press; 2001.

Cannings RA, Cannings RJ, Cannings SG. Birds of the Okanagan Valley, British Columbia. Victoria: Royal British Columbia Museum; 1987.

Capper C-L, Guigueno MF, Sealy SG. Acceptance of simulated cowbird parasitism in a northern population of Red-winged Blackbirds. Am Midl Nat. 2012:167:127-35.

Carello CA, Snyder G. The effects of host numbers on cowbird parasitism of Red-winged Blackbirds. In: Smith JNM, Cook TL, Rothstein SI, Robinson 
SK, Sealy SG, editors. Ecology and management of cowbirds and their hosts. Austin: University of Texas Press; 2000. p. 110-4.

Carey M, Burhans DE, Nelson DA. Field sparrow (Spizella pusilla), version 2.0. In: Poole AF, editor. The birds of North America. Ithaca: Cornell Lab of Ornithology; 2008. https://doi.org/10.2173/bna.103.

Clotfelter ED, Yasukawa K. Impact of brood parasitism by Brown-headed Cowbirds on Red-winged Blackbird reproductive success. Condor. 1999;101:105-14.

Curson DR, Goguen CB, Matthews NE. Community-level patterns of population recruitment in a generalist avian brood parasite, the Brown-headed Cowbird. Oecologia. 2010;163:601-12.

Delphey PJ, Dinsmore JJ. Breeding bird communities of recently restored and natural prairie potholes. Wetlands. 1993;13:200-6.

Elliott PF. Cowbird parasitism in the Kansas tallgrass prairie. Auk. 1978;95:161-7.

Ely CA. Comparative nesting success of certain south-central Oklahoma birds [M.S. thesis]. Norman: University of Oklahoma; 1957.

Facemire CF. Cowbird parasitism of marsh-nesting Red-winged Blackbirds. Condor. 1980:82:347-8.

Feeney WE. Evidence of adaptations and counter-adaptations before the parasite lays its egg: the frontline of the arms race. In: Soler M, editor. Avian brood parasitism: behavior, ecology, evolution and coevolution. Cham: Springer; 2017. p. 307-24.

Fleischer RC. Brood parasitism by Brown-headed Cowbirds in a simple host community in eastern Kansas. Kansas Ornithol Soc Bull. 1986;37:21-9.

Freeman S, Gori DF, Rohwer S. Red-winged Blackbirds and Brown-headed Cowbirds: some aspects of a host-parasite relationship. Condor. 1990;92:336-40.

Friedmann H, Kiff LF, Rothstein SI. A further contribution of knowledge of the host relations of the parasitic cowbirds. Smithson Contr Zool. 1977;235:1-75.

Gardali T, Ballard G. Warbling Vireo (Vireo gilvus), version 2.0. In: Poole AF, Gill FB, editors. The Birds of North America. Ithaca: Cornell Lab of Ornithology; 2000. https://doi.org/10.2173/bna.551.

Gill SA, Sealy SG. Functional reference in an alarm signal given during nest defence: seet calls of Yellow Warblers denote brood-parasitic Brownheaded Cowbirds. Behav Ecol Sociobiol. 2004;56:71-80.

Goertz JW. Additional records of Brown-headed Cowbird nest parasitism in Louisiana. Auk. 1977;94:386-9.

Guigueno MF, Sealy SG. Nest sanitation in passerine birds: implications for egg rejection in hosts of brood parasites. J Ornithol. 2012;153:35-52.

Hahn DC, Hatfield JS. Parasitism at the landscape scale: cowbirds prefer forests. Conserv Biol. 1995;9:1415-24.

Hanka LR. Choice of host nest by the Brown-headed Cowbird in Colorado and Wyoming. Condor. 1979;8:436-7.

Henger CS, Hauber ME. Variation in antiparasitic behaviors of Red-winged Blackbirds in response to simulated Brown-headed Cowbirds. Wilson J Ornithol. 2014;126:488-99.

Hergenrader GL. The incidence of nest parasitism by the Brown-headed Cowbird (Molothrus ater) on roadside nesting birds in Nebraska. Auk. 1962;79:85-8.

Hill RA. Host-parasite relationships of the Brown-headed Cowbird in a prairie habitat of west-central Kansas. Wilson Bull. 1976;88:555-65.

Hosoi S, Rothstein SI. Nest desertion and cowbird parasitism: evidence for evolved responses and evolutionary lag. Anim Behav. 2000;59:823-40.

Houston CS. Northern Great Plains Region. Am Birds. 1973;27:882-6.

Igl LD, Johnson DH. Brown-headed Cowbird, Molothrus ater, parasitism and abundance in the northern Great Plains. Can Field Nat. 2007;121:239-55.

Johnson RG, Temple SA. Nest predation and brood parasitism of tallgrass prairie birds. J Wildl Manag. 1990;54:106-11.

King JR. Victims of the Brown-headed Cowbird in Whitman County, Washington. Condor. 1954;56:150-4.

Koford RR, Bowen BS, Lokemoen JT, Kruse AD. Cowbird parasitism in grassland and cropland in the northern Great Plains. In: Smith JNM, Cook TL, Rothstein SI, Robinson SK, Sealy SG, editors. Ecology and management of cowbirds and their hosts. Austin: University of Texas Press; 2000. p. 229-35.

Kuehn MJ, Peer BD, McCleery RA, Rothstein SI. Yellow Warbler defenses are retained in the absence of brood parasitism but enhanced by experience with cowbirds. Behav Ecol. 2016;27:279-86.
Liang W, Møller AP, Stokke BG, Yang C, Kovařík P, Wang H, Yao C-T, Ding P, Lu X, Moksnes A, Røskaft E, Grim T. Geographic variation in egg ejection rate by Great Tits across 2 continents. Behav Ecol. 2016;27:1405-12.

Linz GM, Bolin SB. Incidence of Brown-headed Cowbird parasitism on Redwinged Blackbirds. Wilson Bull. 1982;94:93-5.

Lowther PE. Old cowbird breeding records from the Great Plains. Bird Band. 1977:48:358-69.

Lowther PE. Chickadee, thrasher, and other cowbird hosts from northwest lowa. J Field Ornithol. 1983;54:414-7.

Lowther PE. Brown-headed Cowbird (Molothrus ater), version 2.0. In: Poole AF, Gill FB, editors. The birds of North America. Ithaca: Cornell Lab of Ornithology; 1993. https://doi.org/10.2173/bna.47.

Mayfield HF. The Brown-headed Cowbird, with old and new hosts. Liv Bird. 1965:4:13-28.

McWilliams GM, Brauning DW. The birds of Pennsylvania. Ithaca: Comstock; 2000.

Merrill L, Chiavacci SJ, Paitz RT, Benson TJ. Rates of parasitism, but not allocation of egg resources, vary among and within hosts of a generalist avian brood parasite. Oecologia. 2017;184:399-410.

Middleton ALA. Effect of Cowbird parasitism on American Goldfinch nesting. Auk. 1977;2000(94):304-7.

Moksnes A, Røskaft E, Braa AT. Rejection behavior by Common Cuckoo hosts towards artificial brood parasite eggs. Auk. 1991;108:348-54.

Moskát C, Hauber ME. Conflict between egg recognition and egg rejection decisions in Common Cuckoo (Cuculus canorus) hosts. Anim Cogn. 2007;10:377-86.

Moskát C, Honza M. European Cuckoo Cuculus canorus parasitism and host's rejection behaviour in a heavily parasitized Great Reed Warbler Acrocephalus arundinaceus population. Ibis. 2002;144:614-22.

Neudorf DL, Sealy SG. Sunrise nest attentiveness in Cowbird hosts. Condor. 1994:96:162-9.

Nickell WP. Notes on Cowbird parasitism on four species. Auk. 1955;72:88-92.

Orians GH, Røskaft E, Beletsky LD. Do Brown-headed Cowbirds lay their eggs at random in the nests of Red-winged Blackbirds? Wilson Bull. 1989;101:599-605.

Ortega CP. The ecology of blackbird/cowbird interactions in Boulder County, Colorado [dissertation]. Bolder: University of Colorado; 1991.

Ortega CP. Cowbirds and other brood parasites. Tucson: University of Arizona Press; 1998.

Ortega CP, Cruz A. Mechanisms of egg acceptance by marsh-dwelling blackbirds. Condor. 1988;90:349-58.

Ortega CP, Ortega JC. Brown-headed Cowbird (Molothrus ater) parasitism on Warbling Vireos (Vireo gilvus) in southwest Colorado. Auk. 2003;120:759-64.

Ortega CP, Ortega JC, Cruz A. Use of artificial Brown-headed Cowbird eggs as a potential management tool in deterring parasitism. J Wildl Manag. 1994;58:488-92.

Patten MA, Shochat E, Reinking DL, Wolfe DH, Sherrod SK. Habitat edge, land management, and rates of brood parasitism in tallgrass prairie. Ecol Appl. 2006;16:687-95.

Payne RB. The breeding season of a parasitic bird, the Brown-headed Cowbird, in central California. Condor. 1973;75:80-99.

Peck GK, James RD. Breeding birds of Ontario: nidiology and distribution—volume 2: passerines. Toronto: Royal Ontario Museum; 1987.

Peer BD. Nest sanitation does not elicit egg ejection in a Brown-headed Cowbird host. Anim Cogn. 2017;20:371-4.

Peer BD, Bollinger EK. Explanations for the infrequent cowbird parasitism on Common Grackles. Condor. 1997;99:151-61.

Peer BD, Sealy SG. Correlates of egg rejection in hosts of the Brown-headed Cowbird. Condor. 2004;106:580-99.

Peer BD, Rivers JW, Rothstein SI. Cowbirds, conservation, and coevolution: potential misconceptions and directions for future research. Chin Birds. 2013:4:15-30.

Peterjohn BG, Sauer JR, Schwartz S. Temporal and geographic patterns in population trends in brown-headed cowbirds. In: Smith JNM, Cook TL, Rothstein SI, Robinson SK, Sealy SG, editors. Ecology and management of cowbirds and their hosts. Austin: University of Texas Press; 2000. p. $21-34$.

Picman J. Attempted nest parasitism of the Marsh Wren by a Brown-headed Cowbird. Condor. 1986;88:381-2. 
Pietz PJ, Buhl DA, Shaffer JA, Winter M, Johnson DH. Influence of trees in the landscape on parasitism rates of grassland passerine nests in southeastern North Dakota. Condor. 2009:111:36-42.

Prather J, Ortega C, Cruz A. Aggressive responses of Red-winged Blackbirds (Agelaius phoeniceus) toward Brown-headed Cowbirds (Molothrus ater) in areas of recent and long-term sympatry. Bird Behav. 1999;13:1-7.

Rivers JW, Jensen WE, Kosciuch KL, Rothstein SI. Community-level patterns of host use by the Brown-headed Cowbird (Molothrus ater), a generalist brood parasite. Auk. 2010;127:263-73.

Robbins CS, Blom EAT. Atlas of the breeding birds of Maryland and the District of Columbia. Pittsburgh: University of Pittsburgh Press; 1996.

Robinson SK, Hoover JP, Herkert JR. Biogeographic, landscape, and local factors affecting cowbird abundance and host parasitism levels. In: Smith JNM, Cook TL, Rothstein SI, Robinson SK, Sealy SG, editors. Ecology and management of cowbirds and their hosts. Austin: University of Texas Press; 2000. p. 280-97

Røskaft E, Moksnes A, Stokke BG, Bicík V, Moskát C. Aggression to dummy cuckoos by potential European cuckoo hosts. Behaviour. 2002;139:613-28.

Rothstein SI. An experimental and teleonomic investigation of avian brood parasitism. Condor. 1975:77:250-71.

Rothstein SI. Model system for coevolution: avian brood parasitism. Annu Rev Ecol Syst. 1990;21:481-508.

Rothstein SI, Peer BD. Conservation solutions for threatened and endangered cowbird (Molothrus spp.) hosts: separating fact from fiction. Ornithol Monogr. 2005;57:98-114.

Ruiz-Raya F, Soler M. Phenotypic plasticity in egg rejection: evidence and evolutionary consequences. In: Soler M, editor. Avian brood parasitism: behavior, ecology, evolution and coevolution. Cham: Springer; 2017. p. 449-71.

Sealy SG. Burial of cowbird eggs by parasitized Yellow Warblers: an empirical and experimental study. Anim Behav. 1995:49:877-89.

Sealy SG. Evolution of host defenses against brood parasitism: implications of puncture-ejection by a small passerine. Auk. 1996;113:346-55.

Sealy SG, Banks AJ, Chace JF. Two subspecies of Warbling Vireo differ in their response to Cowbird eggs. West Birds. 2000;31:190-4.

Smith HM. Irregularities in the egg laying behavior of the eastern cowbird. J Colorado-Wyoming Acad Sci. 1949;4:60.

Soler M, Soler JJ, Martinez JG, Pérez-Contreras T, Møller AP. Micro-evolutionary change and population dynamics of a brood parasite and its primary host: the intermittent arms race hypothesis. Oecologia. 1998;117:381-90.

Soler M, Martín-Vivaldi M, Pérez-Contreras T. Identification of the sex responsible for recognition and the method of ejection of parasitic eggs in some potential Common Cuckoo hosts. Ethology. 2002;108:1093-101.

Southern WE, Southern LK. A summary of the incidence of cowbird parasitism in northern Michigan from 1911-1948. Jack-Pine Warbler. 1980;58:77-84.

Strausberger BM. The relationship of habitat and spatial distribution of nests with Brown-headed Cowbird parasitism of Red-winged Blackbirds. Wilson Bull. 2001;113:129-33.

Strausberger BM, Ashley MV. Community-wide patterns of parasitism of a host "generalist" brood-parasitic cowbird. Oceologia. 1997;112:254-62.

Terrill LM. Cowbird hosts in southern Quebec. Can Field-Nat. 1961;75:2-11.

Thompson FR III, Robinson SK, Donovan TM, Faaborg J, Whitehead DR, Larsen DR. Biogeographic, landscape, and local factors affecting cowbird abundance and host parasitism levels. In: Smith JNM, Cook TL, Rothstein SI, Robinson SK, Sealy SG, editors. Ecology and management of cowbirds and their hosts. Austin: University of Texas Press; 2000. p. 271-9.

Thorogood R, Davies NB. Reed Warbler hosts fine-tune their defenses to track three decades of cuckoo decline. Evolution. 2013;67:3545-55.
Uhrich WD. A century of bird life in Berks County, Pennsylvania. Reading: Reading Public Museum; 1997.

Underwood TJ, Sealy SG. Grasp-ejection in two small ejecters of cowbird eggs: a test of bill-size constraints and the evolutionary equilibrium hypothesis. Anim Behav. 2006a;71:409-16.

Underwood TJ, Sealy SG. Parameters of Brown-headed Cowbird Molothrus ater egg recognition and ejection in Warbling Vireos Vireo gilvus. J Avian Biol. 2006b;37:457-66.

Underwood TJ, Sealy SG. UV reflectance of eggs of Brown-headed Cowbirds (Molothrus ater) and acceptor and rejector hosts. J Ornithol. 2008;149:313-21.

Underwood TJ, Sealy SG, Mclaren CM. Eastern Wood-Pewees as Brown-headed Cowbird hosts: accepters but infrequently parasitized. J Field Ornithol. 2004;75:165-71.

Verner J, Ritter LV. Current status of the Brown-headed Cowbird in the Sierra National Forest. Auk. 1983;100:355-68.

Vierling KT. Source and sink habitats of Red-winged Blackbirds in a rural/suburban landscape. Ecol Appl. 2000;10:1211-8.

Walkinshaw LH. Brown-headed Cowbird Molothrus ater. In: Brewer R, McPeek GA, Adams Jr RJ, editors. The atlas of breeding birds in Michigan. East Lansing: Michigan State University Press; 1991. p. 508-9.

Ward D, Smith JNM. Interhabitat differences in parasitism frequencies by Brown-headed Cowbirds in the Okanagan Valley, British Columbia. In: Smith JNM, Cook TL, Rothstein SI, Robinson SK, Sealy SG, editors. Ecology and management of cowbirds and their hosts. Austin: University of Texas Press; 2000. p. 210-9.

Ward D, Lindholm AK, Smith JNM. Multiple parasitism of the Red-winged Blackbird: further experimental evidence of evolutionary lag in a common host of the Brown-headed Cowbird. Auk. 1996;113:408-13.

Weatherhead PJ. Sex ratios, host-specific reproductive success, and impact of Brown-headed Cowbirds. Auk. 1989:106:358-66.

Welbergen JA, Davies NB. Strategic variation in mobbing as a front line of defense against brood parasitism. Curr Biol. 2009;19:235-40.

Whitehead MA, Schweitzer SH, Post W. Cowbird/host interactions in a southeastern old-field: a recent contact area? J Field Ornithol. 2002;73:379-86.

Wiens JA. Aspects of cowbird parasitism in southern Oklahoma. Wilson Bull. 1963:75:130-9.

Woolfenden BE, Gibbs HL, McLaren CM, Sealy SG. Community-level patterns of parasitism: use of three common hosts by a brood-parasitic bird, the Brown-headed Cowbird. Écoscience. 2004;11:238-48.

Yasukawa K, Searcy WA. Red-winged Blackbird (Agelaius phoeniceus), version 2.0. In: Rodewald PG, editor. The Birds of North America. Ithaca: Cornell Lab of Ornithology; 2019. https://doi.org/10.2173/bna.rewbla.02.

Yasukawa K, Werner W. Nest abandonment as a potential anti-parasite adaptation in the red-winged blackbird. Passeng Pigeon. 2007;69:481-90.

Yasukawa K, Lindsey-Robbins J, Henger CS, Hauber ME. Antiparasitic behaviors of Red-winged Blackbirds (Agelaius phoeniceus) in response to simulated Brown-headed Cowbirds (Molothrus ater): further tests of the frontloaded parasite-defense hypothesis. Wilson J Ornithol. 2016;128:475-86.

Ready to submit your research? Choose BMC and benefit from:

- fast, convenient online submission

- thorough peer review by experienced researchers in your field

- rapid publication on acceptance

- support for research data, including large and complex data types

- gold Open Access which fosters wider collaboration and increased citations

- maximum visibility for your research: over $100 \mathrm{M}$ website views per year

At BMC, research is always in progress.

Learn more biomedcentral.com/submissions 